\title{
KARTU KREDIT SYARIAH DAN PERILAKU KONSUMTIF MASYARAKAT
}

\author{
Dewi Sukma Kristianti \\ Fakultas Hukum Universitas Katholik Parahyangan Bandung \\ Jl. Ciumbuleuit Nomor 94 Bandung Jawa Barat \\ E-mail: deeska1978@gmail.com
}

\begin{abstract}
Islamic Credit Cards and Consumptive Behaviour of Society. The credit card as one means of payment utilising cards, is a payment system that is growing rapidly, brought about by the security and risk of carrying cash in large amounts, efficiency, speed and ease of transaction that is offered. Islamic banks are glancing consumer funding products as one of the products services to be offered. There is a very important limitation that must be realized for Islamic banks, namely the provisions of the shari'a principles regarding the provision of credit card and influence on consumer behaviour society, particularly the Muslim community. It is not impossible for the existence of Islamic credit cards that are presented for the ease of transacting to become a card for the ease of indebtedness and cause a consumptive/wasteful attitude that is definitely forbidden in Islamic economic concept.
\end{abstract}

Keywords: Islamic credit card, Islamic principles, consumptive attitude, Islamic economic

\begin{abstract}
Abstrak. Kartu Kredit Syariah dan Perilaku KonsumtifMasyarakat. Kartu kredit sebagai salah satu alat pembayaran menggunakan kartu, merupakan sistem pembayaran yang berkembang dengan pesat dikarenakan keamanan dari risiko membawa uang tunai dalam jumlah banyak, efisien, cepat dan kemudahan bertransaksi yang ditawarkan. Bank syariah melirik produk pembiayaan konsumer tersebut sebagai salah satu produk jasa yang ditawarkan. Ada batasan sangat penting yang harus disadari oleh bank syariah, yaitu ketentuan dalam prinsip syariah mengenai ketentuan kartu kredit dan pengaruhnya pada perilaku konsumtif masyarakat, khususnya masyarakat Muslim. Sebab bukan tidak mungkin, kehadiran kartu kredit syariah yang dihadirkan untuk kemudahan bertransaksi menjadi kartu untuk kemudahan berhutang dan menyebabkan sikap konsumtif atau pemborosan yang dilarang dalam konsep ekonomi syariah.
\end{abstract}

Kata kunci: kartu kredit syariah, prinsip syariah, perilaku konsumtif, ekonomi syariah

\section{Pendahuluan}

Pasca krisis ekonomi melanda Indonesia, yang disebabkan oleh praktik buruk dalam pengelolaan perbankan, menyebabkan masyarakat mulai melirik pengelolaan sistem perbankan syariah, dikarenakan sistem perbankan syariah mampu menjadi jawaban atas krisis keuangan yang terjadi saat itu. Hal ini kemudian menyebabkan banyaknya bank-bank konvensional yang membuka atau menjadi bank syariah.

Secara teoretis, perbankan syariah memiliki keunggulan yang terletak pada sistem yang berdasarkan atas prinsip bagi hasil (profit and lost sharing) dan berbagi risiko (risk sharing). Sistem ini merupakan salah satu sistem yang dapat menjadi cara untuk menghindari penerimaan dan pembayaran riba/bunga. Konsep ekonomi syariah bukan berarti melarang memperoleh keuntungan/laba, tetapi melarang memungut keuntungan yang merupakan bunga. Sebab bunga/riba

Naskah diterima: 25 Februari 2014, direvisi: 10 April 2014, disetujui untuk terbit: 20 Mei 2014. merupakan keuntungan yang dihasilkan dari adanya pemberian beban kepada salah satu pihak yang besar jumlahnya tidak pasti karena tidak menggantungkan pada hasil yang nyata yang diperoleh. ${ }^{1}$

Gambaran demikian sebenarnya memberikan peluang bagi perbankan syariah untuk mengembangkan dan meluaskan jangkauan pengelolaannya di masyarakat. Melalui pelbagai macam produk perbankan syariah yang ditawarkan dan kemudahan-kemudahan kerjasama dengan pelbagai pihak dalam meningkatkan profit/keuntungan melalui pemasaran besar-besaran di masyarakat menyebabkan tidak hanya masyarakat Muslim yang tertarik, tetapi juga masyarakat nonMuslim untuk menjadi nasabah dan menggunakan pelbagai macam tawaran produk perbankan syariah.

Salah satu produk perbankan syariah yang cukup berkembang adalah kartu kredit syariah, yang lebih dikenal dengan nama produk kartu syariah (sharia card).
1 Zainul Arifin, Memahami Bank Syariah, Lingkup, Peluang, Tantangan dan Prospek, (Jakarta: Alvabet, 1999), h. 125. 
Berkembangnya kartu kredit syariah dalam masyarakat disebabkan salah satunya adalah faktor situasi dan kondisi dalam masyarakat yang sedang menuju less cash society. Era globalisasi seperti saat ini, dimana teknologi telah menguntungkan untuk melakukan transaksi secepat mungkin, sehingga dunia perbankan syariah pun dituntut untuk melakukan hal tersebut bagi para nasabahnya. Maka dari itu, munculnya kartu syariah akan sangat dibutuhkan dalam memberikan kemudahan transaksi yang dilakukan dan juga sebagai jawaban atas pertanyaan yang meragukan keberadaan perbankan syariah dalam kegiatan keuangan dan ekonomi modern. ${ }^{2}$

Pengaturan mengenai hukum kartu syariah adalah boleh menurut ketentuan-ketentuan yang didasarkan pada Fatwa Dewan Syariah Nasional (DSN) Majelis Ulama Indonesia (MUI) No.54/DSN-MUI/2006, yang kemudian diikuti dalam regulasi pemerintah sebagai peraturan pelaksana dari fatwa tersebut. Fatwa tersebut merujuk pada konsep syariah muamalat yang menyatakan bahwa hukum setiap kegiatan muamalat dasarnya adalah boleh sepanjang tidak bertentangan dengan prinsip syariah yang sudah jelas diatur larangannya. Artinya, kehadiran dan keberadaan kartu syariah adalah boleh sepanjang tidak ada hal-hal yang mengandung kegiatan yang dilarang/diharamkan.

Di dalam Fatwa DSN-MUI No.54/DSN-MUI/2006 terdapat beberapa ketentuan yang menjadi batasan pada kartu kredit syariah, yaitu: (1) Tidak boleh menimbulkan riba. (2) Tidak boleh digunakan untuk transaksi objek yang haram atau maksiat. (3) Tidak mendorong isrâf (pemborosan) antara lain dengan menetapkan pagu maksimal pembelanjaan. (4) Tidak mengakibatkan hutang yang tidak pernah lunas (ghalabah al-dayn). (5) Pemegang kartu utama harus memiliki kemampuan finansial untuk melunasi tepat pada waktunya. (6) Penerbit kartu tidak diperbolehkan memberikan fasilitas yang bertentangan dengan syariah.

Oleh karena itu, pada tahun 2007 Bank Indonesia (BI) mengeluarkan regulasi berupa Surat Bank Indonesia No.9/183/DPbS/2007 tentang kartu kredit syariah. Regulasi ini menjadi landasan hukum bagi bankbank syariah untuk menerbitkan kartu kredit syariah. Dalam perkembangannya, pemerintah mengeluarkan regulasi melalui Peraturan Bank Indonesia (PBI) No.11/11/PBI/2009 tentang penyelenggaraan kegiatan alat pembayaran dengan menggunakan kartu yang kemudian diubah dengan PBI Nomor 14/2/PBI/2012, menyebabkan terjadinya pengetatan bisnis kartu kredit sehingga banyak bank-bank yang menarik peredaran kartu kreditnya karena tidak banyak menghasilkan profit/keuntungan, termasuk pula yang terjadi pada peredaran kartu syariah di bank syariah seperti Bank Danamon yang pada Tahun 2007 mengeluarkan dirham card harus menarik peredarannya pada tahun 2013. Kartu syariah adalah salah satu alat pembiayaan konsumer dengan menggunakan kartu pada perbankan syariah di Indonesia. Namun jika kita melihat customer based bank syariah di Indonesia sebenarnya masih minim sehingga untuk memasarkan kartu pun masih sangat kurang. Akibatnya, model pembiayaan konsumer tersebut mengalami persaingan ketat dengan kartu kredit konvensional. ${ }^{3}$

Persoalan yang ingin diangkat oleh penulis bukan sebatas pada boleh tidaknya kartu syariah dan apa saja batasan-batasan serta kendalanya, tetapi penulis ingin menarik masalah kartu syariah ini ke dalam perilaku konsumtif yang ditimbulkan dari kemudahankemudahan penggunaan kartu tersebut dalam bertransaksi dalam memenuhi kebutuhan konsumsi di masyarakat. Tawaran-tawaran melalui pemasaran yang dikemas secara apik dan menarik perhatian masyarakat, ditambah kerjasama produsen dan distributor barang dan jasa dengan bank penyedia produk berupa kartu syariah, dapat meningkatkan keinginan masyarakat untuk memenuhi kebutuhan konsumsinya di luar batas kemampuan dan kebutuhan.

Kemudahan akses ke bank dan transaksi secara non tunai secara cepat dan mudah akan berdampak pada keinginan mendapatkan barang dan jasa secara lebih mudah.

Sedangkan dalam konsep ekonomi syariah, salah satu perilaku yang harus dipegang teguh dan dijalani sebagai Muslim yang meyakini sistem syariah sebagai panduan hidup dalam memenuhi kebutuhan hidupnya, adalah berupa perilaku konsumen yang tidak boros/ tidak bersikap konsumtif. Sebab dengan perilaku konsumen yang konsumtif maka jumlah dana/simpanan masyarakat akan semakin minim diakibatkan pola pikir dan kepuasan masyarakat yang mendapatkan barang dan jasa yang ditawarkan, sementara dana/simpanan masyarakat merupakan salah satu sumber peningkatan kesejahteraan umat manusia sebagai modal usaha yang harus dijalani secara berkelanjutan tanpa putus.

Maka dari itu, dengan dikeluarkannya kartu syariah yang merupakan kartu untuk pembiayaan konsumer dalam perbankan syariah sebagai upaya mempermudah bertransaksi bagi masyarakat, apakah hal ini tidak 
menjadikannya perilaku konsumtif masyarakat semakin meningkat, sementara laju pendapatan tidak mengalami peningkatan yang sama pesatnya.

Penggunaan kartu kredit syariah (sharia card) pada dasarnya adalah alat pembayaran berupa kartu yang juga dikenal dalam kegiatan perbankan konvensional. Penggunaan kartu dalam bidang keuangan (financial card) dianggap sebagai salah satu sistem dalam praktek ekonomi dan perdagangan yang memiliki efektivitas dan keuntungan cukup tinggi. Penggunaan financial card ini tidak dapat dilepaskan dari bagaimana karakteristik masyarakat sebagai konsumen sehingga dapat menarik mereka melalui iklan-iklan yang hanya difokuskan pada hal yang positif saja dari kartu tersebut, misalnya berupa aspek keamanan dari menghindari membawa uang tunai dalam jumlah banyak, aspek prestise dan pemuasan keinginan akan ambisi memperoleh materi dengan cara pembayaran melalui kartu kredit syariah atau sharia card. ${ }^{4}$

Lalu bagaimanakah penggunaan kartu syariah/kartu kredit syariah ini jika dikaitkan dengan beberapa aspek di atas yang menjadi latar belakang dikeluarkannya produk berupa financial card. Apakah penggunaan kartu syariah yang merupakan financial card yang memiliki fungsi yang sama dengan kartu kredit bank konvensional, yaitu mempermudah dalam bertransaksi, tidak membawa dampak adanya perilaku konsumtif masyarakat dalam memperoleh barang dan jasa sematamata demi ambisi memperoleh materi dan kebahagiaan sesaat. Apakah ini menjadi selaras dengan tujuan terbentuknya sistem perbankan syariah yaitu pada upaya mendorong peningkatan sektor usaha produktif? Karena pada faktanya, sebagaimana telah dipaparkan di atas, bahwa kartu kredit syariah/kartu syariah banyak dibutuhkan dan digunakan hanya sebagai alat pembayaran/pembiayaan konsumer yang praktis, aman dan fleksibel dalam bertransaksi semata, bukan sebagai komoditi/produk penghasil keuntungan bagi bank syariah.

Berdasarkan beberapa persoalan di atas, maka penulis akan mengkaji bagaimana perilaku konsumtif masyarakat Muslim berdasarkan konsep ekonomi syariah, ketentuan-ketentuan yang berlaku mengenai akad dan penggunaan kartu kredit syariah serta perilaku konsumtif masyarakat Muslim Indonesia terhadap penggunaan produk bank syariah berupa kartu kredit syariah?

\footnotetext{
${ }^{4}$ Mujiatun Ridawati, "Konsep Kartu Kredit (Bithâqah I'timân) sebagai Alat Pembayaran dalam Hukum Islam, dalam www.wordpress. com, diunduh pada tanggal 19 Juli 2013.
}

\section{Perilaku Konsumen dalam Konsep Ekonomi Syariah}

Penggunaan kartu syariah sebagai salah satu financial cardsebagaimanayang telah dijelaskan di atas merupakan suatu kegiatan pembiayaan yang ditujukan sebagai pembiayaan konsumer, yang menurut hemat penulis memiliki korelasi dengan bagaimana pola konsumsi para konsumen di masyarakat. Dalam kerangka acuan Islami sebenarnya tidak menerima formulasi mengenai teori perilaku konsumen dengan alasan bahwa teori tersebut merupakan nilai-nilai yang diadopsi oleh nilainilai ideologik dan sosial masyarakat bukan Muslim. ${ }^{5}$

Teori konsumsi yang dikembangkan di Barat setelah timbulnya kapitalisme merupakan sumber dualitas, yaitu rasionalisme ekonomik dan utilitarinisme. Rasionalisme ekonomik adalah suatu kegiatan menafsirkan perilaku manusia yang dilandasi dengan perhitungan cermat, yang diarahkan dengan pandangan ke depan dan persiapan terhadap keberhasilan ekonomik. ${ }^{6}$ Tolak ukur dari ada atau tidak keberhasilan ekonomik adalah didefinisikan sebagai membuat uang dari manusia, memperoleh harta, baik dalam pengertian uang atau pelbagai komoditas, adalah tujuan hidup yang terakhir dan pada saat yang sama merupakan tongkat pengukur keberhasilan ekonomi.

Sedangkan yang dimaksud dengan utilitarinisme adalah sumber nilai-nilai dan sikap-sikap moral, yang dilandasi oleh ketepatan waktu, kejujuran, ketekunan bekerja dan sikap hemat. ${ }^{\text {? }}$

Dari dua nilai itulah yang kemudian melahirkan teori perilaku konsumen, yang mempertimbangkan maksimisasi pemanfaatan sebagai tujuan konsumer yang dipostulasikan. Pemanfaatan yang dimaksimisasikan adalah pemanfaatan homo economicus, yang memiliki tujuan tunggalnya adalah mendapatkan kepuasan ekonomik pada tingkatan tertinggi dan dorongan satu-satunya adalah kesadaran akan uang. Maka jika kita melihat teori perilaku konsumen dalam sistem kapitalis telah melampui dua tahap. Tahap pertama berkaitan dengan teori marginalis, yaitu berdasarkan teori pemanfaatan konsumen secara tegas dapat diukur dalam satuan-satuan pokok. Konsumen akan mencapai keseimbangannya ketika dapat memaksimisasikan pemanfaatan sesuai keterbatasan penghasilan. Tahap

${ }^{5}$ Syaykh Mahmûd Ahmad, Economics of Islam, (Lahore: Ashraf Publications,1968), h. 45, Mannan, Islamic Economics, (Lahore: Ashraf Publications, 1970), h. 34 dan Mo'tamar al-Alam al-Islami, Quelques Aspects Economiques de l' Islam, (Karachi: Mo'tamar al-Alam al-Islami, 1964), h. 19-20.

${ }^{6}$ Max Weber, The Protestant Ethic and The Spirit of Capitalism, (New York: Charles Scribners Sons, 1958), h. 26.

${ }^{7}$ Max Weber, The Protestant Ethic and The Spirit of Capitalism, h. 52. 
kedua adalah yang lebih modern dalam mengukur dan mengatur kardinalitas pemanfaatan tersebut dengan melihat kesamaan tarif marginal substitusinya. ${ }^{8}$

Perilaku konsumtif atau sikap konsumer dalam pandangan ekonom Barat dianggap sebagai suatu perilaku jangka pendek di saat banyak faktorfaktor sosio-kultural tetap tidak berubah, kemudian membiarkan variabel-variabel ini tidak mengalami suatu perubahan maka dapat diperkirakan bahwa konsumer menjadi berdaulat/berkuasa dan ia dapat bersikap rasional dengan cara memaksimalkan penggunaannya dan meminimalkan biayanya. Analisis ekonom Barat tersebut dibuat berdasarkan variabel-variabel pasar semata dan variabel-variabel non pasar dikunci. ${ }^{9}$

Hal ini berbeda dengan teori perilaku konsumsi dalam pandangan Islam yang memiliki etika konsumsi. Etika konsumsi menurut Islam adalah bahwa anugerahanugerah Allah itu milik semua manusia dan suasana yang menyebabkan sebagian di antara anugerahanugerah itu berada di tangan orang-orang tertentu tidak berarti bahwa mereka dapat memanfaatkan anugerah itu untuk mereka sendiri. Ayat Alquran yang mengajarkan etika konsumsi dalam perilaku konsumtif antara lain adalah Q.s. al-Baqarah [2]: 168 yang memerintahkan manusia agar mengkonsumsi sesuatu yang ada di muka bumi dengan cara halal dan baik (thayyib).

Perilaku konsumtif dalam pandangan ekonomi syariah yang sah dan baik sangat mempengaruhi kegiatan keuangan dan perekonomian masyarakat. Perilaku konsumtifatau sikap konsumer adalah sebuah fenomena yang cukup rumit karena perilaku ini dipengaruhi oleh beberapa hal, antara lain: kekuatan, kebiasaan, adat istiadat, gaya hidup, kepercayaan agama dan sumber daya yang dapat digunakan oleh individu. ${ }^{10}$

Konsep konsumsi dalam ekonomi Islam memandang bahwa hak memang penting karena dikaitkan dengan syariah yang mengatur sikap konsumer. Alquran menyebutnya dengan istilah iqtishâd (penghematan ekonomi) yang secara literal berarti moderasi. Tetapi dalam konteks syariah secara keseluruhan, ia adalah sebuah kelompok nilai (a cluster of values). Maka setiap Muslim diminta mengambil sebuah sikap moderat dalam memperoleh dan menggunakan sumber daya. Dua sikap konsumer yang ekstrim menurut konsep ekonomi Islam, adalah isrâf (royal) dan bukhl (pelit).

\footnotetext{
${ }^{8}$ Max Weber, The Protestant Ethic and The Spirit of Capitalism, h. 52.

${ }^{9}$ Max Weber, The Protestant Ethic and The Spirit of Capitalism, h. 52.

${ }^{10}$ Muhammad Akram Khan, Ajaran Nabi Muhammad Saw. tentang Ekonomi (Kumpulan Hadits-Hadits Pilihan tentang Ekonomi), (Jakarta: Bank Muamalat Indonesia, 1997), h. 89.
}

Dua perilaku tersebut adalah sikap yang dikutuk oleh Alquran dan Sunah Nabi Muhammad Saw. ${ }^{11}$ Isrâf atau pemborosan adalah tindakan menghambur-hamburkan harta tanpa ada manfaatnya. Dalam konsep Hukum Islam, orang yang melakukan tindakan isrâf ini perlu dikenakan pembatasan-pembatasan hingga pencabutan kepengurusan harta miliknya sendiri. ${ }^{12}$

Perilaku konsumtif/sikap konsumer yang ditunjukan oleh Rasul semasa hidupnya adalah sederhana, bersahaja dan konsumsi rendah. Inilah yang kemudian menjadi cara hidup masyarakat Islam. Rasul meminta agar masyarakat tidak hidup dalam kemewahan (tanâum) dan mengharamkan konsumsi segala barang yang akan membawa pada cara hidup dalam kemewahan. ${ }^{13}$

Konsep ekonomi syariah menggambarkan suatu sistem ekonomi dengan biaya dan konsumsi rendah. Sumber daya minimum digunakan untuk keperluankeperluan konsumer. Pandangan umum Islam tentang kehidupan dunia ini sebagai fase sementara dalam menuju perjalanan ke akhirat sehingga pandangan dari setiap Muslim dalam menilai kehidupan dunia ini adalah sebagai timbangan rendah. Disamping membatasi tingkat konsumsi pada batas minimum, hal penting yang harus dilakukan adalah surplus/kelebihan harta yang dimiliki harus dapat disebarluaskan secara sosial, yang dikenal dengan istilah infak. ${ }^{14}$

Dalam perekonomian syariah, beberapa hal yang harus dipenuhi atau kewajiban yang harus ditaati oleh pelaku ekonomi adalah: ${ }^{15}(1)$ Kebebasan dalam berekonomi, yang dibedakan menjadi dua hal, yaitu kebebasan eksistensial yang berkaitan dengan kemampuan seseorang dan kebebasan sosial yang menekankan kebebasan individu karena kepentingan bersama. (2) Keseimbangan hak individu dan hak kolektif sebagai konsekuensi dari kegiatan yang dibangun atas dasar kebersamaan. (3) Berorientasi pada kemaslahatan dan manfaat. (4) Etika ekonomi dan bisnis yang mendasarkan pada prinsip otonomi, prinsip kejujuran dan prinsip keadilan.

Masyarakat Islam mengatur tingkah laku manusia dengan suatu tata nilai tertentu. Sebagian dari nilai-nilai ini mempengaruhi tingkah laku ekonomi masyarakat secara vital. Dengan ekonomi, kita memasukkan aktivitas-aktivitas masyarakat yang berhubungan dengan

\footnotetext{
${ }^{11}$ Muhammad Akram Khan, Ajaran Nabi Muhammad Saw. tentang Ekonomi (Kumpulan Hadits-Hadits Pilihan tentang Ekonomi), h. 90.

${ }_{12}$ Afzalur Rahman, Doktrin Ekonomi Islam, (Jakarta: Penerbit Dana Bhakti Wakaf, 1995), Jilid 1, h. 81.

${ }^{13}$ Afzalur Rahman, Doktrin Ekonomi Islam, h. 91.

${ }^{14}$ Afzalur Rahman, Doktrin Ekonomi Islam, h. 91-92.

15 Ismail Nawawi, Ekonomi Kelembagaan Syariah dalam Pusaran Perekonomian Global; Sebuah Tuntutan dan Realitas, (Surabaya: Putra Media Nusantara, 2009), h. 19-23.
} 
produksi, pertukaran serta konsumsi barang-barang dan pelayanan jasa. Nilai-nilai ini akan menghasilkan sebuah pola tingkah laku yang dapat diakui dan dibenarkan secara sosial, sebab nilai-nilai tersebut adalah untuk mempertahankan kerangka kerja hukum.

\section{Kartu Kredit Syariah (Sharia Card) Sebagai Pembiayaan Konsumer}

Istilah kartu kredit yang lazim dipakai oleh para ekonom dan praktisi perbankan syariah adalah bithâqah al-i'timâniyyah. Secara etimologi, kata bithâqah berarti kartu. Pengertian kata "kartu" menurut tata bahasa adalah potongan kertas kecil atau dari bahan lain, di atasnya ditulis penjelasan yang berkaitan dengan potongan kertas itu. Sedangkan pengertian dari kata ali'timâniyyah secara etimologi adalah saling percaya atau kondisi aman. ${ }^{16}$

Secara terminologis, kartu kredit adalah suatu jenis alat pembayaran sebagai pengganti uang tunai, yang sewaktu-waktu dapat ditukarkan apa saja yang diinginkan dimana saja ada cabang yang dapat menerima kartu kredit dari bank atau perusahaan yang mengeluarkannya. Pengertian lainnya yang lebih rinci dari kartu kredit ini adalah uang plastik yang diterbitkan oleh suatu institusi yang memungkinkan pemegang kartu untuk memperoleh kredit atas transaksi yang dilakukannya dan pembayarannya dapat dilakukan secara angsuran dengan membayar sejumlah bunga (finance charge) atau sekaligus pada waktu yang telah ditentukan. ${ }^{17}$ Pengertian kartu kredit lainnya adalah kartu yang dikeluarkan oleh pihak bank dan sejenisnya yang dapat digunakan oleh pembawanya untuk membeli segala keperluan barang-barang serta pelayanan tertentu secara hutang. ${ }^{18}$

Kartu kredit pada awal tahun 2000-an telah menjadi wacana serius di kalangan ulama, akademisi maupun praktisi perbankan syariah seiring dengan kemajuan perbankan dan transaksi-transaksi keuangan syariah di Indonesia. Meskipun telah banyak yang menerbitkan, namun persoalan yang berkaitan dengan kartu kredit syariah tersebut hingga saat ini masih menjadi polemik di pelbagai kalangan industri perbankan syariah. ${ }^{19}$

Sebagai perwujudan pelayanan bagi perbankan

${ }^{16}$ Abdul Wahab Ibrahim Abu Sulaiman, Banking Cards Syariah Kartu Kredit dan Debit dalam Perspektif Fiqih, (Jakarta: Raja Grafindo Persada, 2006), h. 2.

${ }_{17}$ Gemala Dewi, dkk., Hukum Perikatan Islam di Indonesia, (Jakarta: Kencana, 2006), Edisi 1, Cet. 2, h. 208.

${ }^{18}$ Abdullah Mushlih dan Shalah Shawi, Fiqih Ekonomi Keuangan Islam, (Jakarta: Darul Haq, 2004), h. 304.

19 Abdul Aziz dan Mariyah Ulfah, Kapita Selekta Ekonomi Islam Kontemporer, (Bandung: Penerbit Alfabeta, 2010), h. 244. syariah, Dewan Syariah Nasional-Majelis Ulama Indonesia (DSN-MUI) telah mengeluarkan pelbagai fatwa tentang sejumlah produk pelayanan bagi nasabah, antara lain Syariah Charge Card dan Sharia Card (kartu kredit syariah). Sekalipun keduanya samasama merupakan produk perbankan syariah dalam bentuk kartu, namun tetap memiliki perbedaan. Sharia Charge Card menurut Fatwa DSN-MUI Nomor 42/DSN-MUI/V/2004 yang dikeluarkan pada tanggal 27 Mei 2004 adalah fasilitas kartu talangan yang dipergunakan oleh pemegang kartu sebagai alat bayar atau pengambilan uang tunai pada tempattempat tertentu yang harus dibayar lunas kepada pihak yang memberikan talangan, dalam hal ini bank syariah sebagai penerbit kartu, berdasarkan waktu yang telah ditetapkan. Secara konsepsi, sharia charge card merupakan alternatif dari produk kartu kredit yang dapat memberikan kemudahan, keamanan dan kenyamanan bagi nasabah dalam melakukan transaksi dan penarikan tunai yang memerlukan charge card. Pada prinsipnya, sharia charge card adalah dibolehkan karena berdasarkan metode penemuan hukum qiyas berdasarkan beberapa transaksi, antara lain transaksi pembiayaan ijârah, kafâlah, wakâlah, murâbahah dan qardh.

Sharia card atau kartu kredit syariah pada dasarnya hampir tidak ada perbedaan yang sangat mendasar dengan sharia charge card. Yang membedakan keduanya adalah di dalam sharia charge card tidak terdapat ketentuan mengenai $t a$ 'wîdh (ganti rugi) sebagaimana halnya yang diatur di dalam ketentuan sharia card atau kartu kredit. Pengertian kartu kredit syariah adalah kartu yang berfungsi sebagai kartu kredit yang memiliki hubungan hukum (berdasarkan sistem yang sudah ada) antara para pihak berdasarkan prinsip syariah. Yang dimaksud dengan para pihak disini adalah penerbit kartu atau mushdir al-bithâqah, pemegang kartu atau hâmil bithâqah dan penerima kartu dalam hal ini adalah merchant atau qâbil al-bithâqah. ${ }^{20}$

Fatwa DSN-MUI No.54/DSN-MUI/X/2006 telah memberikan ketentuan mengenai diperbolehkan pengenaan fee atas transaksi yang terjadi. Penerbit kartu dalam hal ini diperbolehkan mengenakan membership fee (rusûm al-udhwiyyah), berupa iuran keanggotaan termasuk perpanjangan masa keanggotaan dari pemegang kartu sebagai imbalan izin menggunakan kartu yang pembayarannya berdasarkan kesepakatan. Bagi pihak merchant pun diperbolehkan memberikan fee kepada penerbit kartu sehubungan dengan transaksi

${ }^{20}$ Abdul Aziz dan Mariyah Ulfah, Kapita Selekta Ekonomi Islam Kontemporer, h. 248. 
yang menggunakan kartu sebagai upah/imbalan atau ujrah atas jasa perantara, pemasaran dan penagihan. Pembebanan fee juga dapat dibebankan pada transaksi penarikan tunai atau biasa disebut dengan rusûm sahb $b$ al-nuqûd yang merupakan fee atas pelayanan dan penggunaan fasilitas yang besarnya tidak dikaitkan dengan jumlah penarikan. Apabila terjadi keterlambatan dalam membayar kewajiban yang telah jatuh tempo, maka penerbit diperbolehkan mengenakan ta'wîdh atau ganti rugi terhadap biaya-biaya yang dikeluarkan oleh penerbit kartu pada si pemegang kartu. Pengenaan denda akibat keterlambatan pembayaran (late charge) akan diakui sebagai dana sosial dan bukan menjadi hak bank. Ketentuan ini harus telah ditetapkan pada saat akad aplikasi kartu secara jelas dan tetap.

Transaksi keuangan yang menggunakan kartu kredit syariah akan dijumpai tidak hanya transaksi antara dua pihak, tetapi tiga pihak sekaligus yang saling berkaitan, yaitu penerbit kartu, pemegang kartu dan merchant. Ketika hal itu diterapkan dalam transaksi syariah, konsekuensinya adalah akan memiliki lebih dari satu akad, misalnya akad transaksi antara penerbit kartu dengan pemegang kartu, akad transaksi antara pemegang kartu dengan merchant dan akad transaksi antara penerbit kartu dengan merchant. Dengan demikian ada 3 macam akad yang mendasari kartu kredit syariah, yaitu akad kafâlah (perjanjian penanggungan), qardh (perjanjian kredit) dan wakalah (perjanjian pemberian kekuasaan). Namun beberapa kalangan ada yang mengatakan beberapa macam akad dalam kartu kredit syariah, antara lain, akad al-âriyah, wakâlah dan kafâlah. ${ }^{21}$

Untuk dapat menggunakan kartu kredit syariah harus dapat memenuhi beberapa kriteria yang diberikan kepada setiap pengguna kartu kredit syariah, antara lain bahwa nasabah pengguna harus memiliki pendapatan/ gaji yang laik dan sesuai dengan kebutuhan serta pengguna kartu harus memiliki kemampuan secara finansial untuk melunasi pembayaran pada waktunya. Hal ini dimaksudkan agar dapat menghindari ketidakmampuan membayar di saat penagihan. Disamping kriteria tersebut, kartu kredit syariah akan diberikan batasan dari besaran pembelanjaan atas transaksi yang dilakukan oleh pihak pengguna kartu/ nasaba. Ada batasan maksimal yang dipatok oleh pihak penerbit kartu kredit syariah di saat nasabah melakukan transaksi. Ditambahkan pula bahwa penggunaan kartu kredit tidak dapat digunakan untuk melakukan transaksi atas barang-barang yang diharamkan sehingga

${ }^{21}$ Abdul Wahab Ibrahim Abu Sulaiman, Banking Cards Syariah Kartu Kredit dan Debit dalam Perspektif Fiqih, h. 73. kartu kredit syariah hanya dapat diakses transaksinya pada barang-barang yang telah ditentukan kriteria kehalalannya.

Kartu kredit syariah tidak jauh berbeda dengan kartu kredit konvensional, tetap ada penambahan/margin nilai pembayaran yang dibayar kepada bank, tetapi bukan riba. Margin nilai itu disebut rib $\underline{h}$ untuk transaksi barang dagang. Berdasarkan pemaparan tersebut, kartu kredit syariah ini lebih dipandang sebagai produk perbankan yang lebih memperluas pangsa pasar. Kartu kredit konvensional merupakan suatu alat pembayaran dalam kegiatan pembiayaan konsumer yang terikat dalam suatu perjanjian. Hubungan kontraktual kartu kredit berasal dari inisiatif pihak-pihak, terutama konsumen sebagai pembeli dan nasabah bank. Dilihat dari sisi perjanjiannya memiliki 2 (dua) perjanjian, yaitu, perjanjian penerbitan kartu sebagai perjanjian pokok dan perjanjian penggunaan kartu kredit sebagai perjanjian pelengkap. Artinya, pembeli atau konsumen tidak akan dapat membeli barang/jasa dari penjual apabila pembeli tidak melakukan perjanjian penerbitan kartu kredit terlebih dahulu dan penjual tidak dapat menagih pada pihak penerbit apabila pembeli tidak mengadakan perjanjian penerbitan kartu kredit terlebih dahulu kepada pihak penerbit. Dengan demikian, kartu kredit merupakan sumber terjadinya jual beli dan pembayaran, bukan sebaliknya.

Konsep kredit, hutang piutang atau pinjam meminjam dalam konsep syariah yang dikenal dengan istilah qardh, yaitu pemberian harta kepada orang lain yang dapat ditagih dan diminta kembali atau dengan kata lain meminjamkan tanpa mengharapkan imbalan. Dalam literatur fikih klasik, qardh dikategorikan dalam akad tathawwu' atau akad saling membantu, bukan merupakan akad dalam transaksi komersial. Untuk meyakinkan pihak yang meminjamkan, maka pihak peminjam biasanya menyertai perjanjian tersebut dengan sejumlah benda sebagai jaminan. Maka jika perjanjian kartu kredit syariah ini didasarkan pada akad qardh, pemegang kartu kredit syariah/nasabah harus menyetor sejumlah uang sebagai deposit yang akan menjadi agunan sekaligus limit kreditnya. Kemudian deposit tersebut disimpan oleh bank dalam bentuk deposito atau tabungan yang tidak bisa ditarik sebagai adanya itikad baik dari nasabah. Dari sini dapat terlihat adanya suatu gambaran bahwa orang yang menjadi nasabah kartu kredit adalah orang yang hendak berhutang, tetapi di sisi lain justru harus mempunyai uang terlebih dahulu untuk dijadikan deposito agunan. ${ }^{22}$

\footnotetext{
${ }^{22} \mathrm{Http} / / /$ safruddin.wordpress.com/, diunduh pada 25 Juli 2013.
} 
Jika fatwa tentang kartu kredit syariah dilihat kembali, maka akan ditemukan ketidakkonsistenan penggunaan akad/perjanjian yang mendasari kartu kredit syariah ini, yaitu dengan adanya istilah menggunakan akad qardh dan juga di pihak lain dapat mengenakan dayn/ penagihan.

Persoalan kartu kredit syariah ini tidak hanya terpaku pada konsep perjanjian saja, tetapi meliputi pula pembahasan ekonomi kelembagaan syariah yang berkaitan dengan ketentuan normatif dalam sistem ekonomi syariah yang harus menjadi pedoman bagi para pelakunya dalam segala kegiatan ekonomi.

Keberhasilan suatu kegiatan dalam ekonomi syariah tergantung pada 4 (empat) hal, yaitu: (1) Keberhasilan sebuah aktivitas itu ditentukan oleh kekuatan (lâ ghalabah illâ bi al-quwwah). (2) Kekuatan itu terbangun dari kebersamaan (lâ quwwah illâ bi al-ittihâad). (3) Kebersamaan itu ada bila saling menghargai peran dan profesi masing-masing orang (lâ ittihâad illâ bi alfadhâil). (4) Orang-orang yang saling menghargai itu berpedoman pada aturan (lâ fadhâil illâ bi al-nizhâm).

\section{Dampak Penggunaan Kartu Kredit Syariah terhadap Perilaku Konsumtif Masyarakat Muslim Indonesia}

Perilaku konsumen, menurut John C. Mowen dan Michael Minor, adalah studi tentang unit pembelian dan proses pertukaran yang melibatkan perolehan, konsumsi pelbagai produk, jasa dan pengalaman serta ide-ide. Sedangkan menurut Lamb, Hair dan Mc. Daniel perilaku konsumen adalah proses seorang pelanggan dalam membuat keputusan untuk membeli, menggunakan serta mengkonsumsi barang-barang dan jasa yang akan dibeli, juga termasuk faktor-faktor yang mempengaruhi keputusan pembelian dan penggunaan produk. ${ }^{23}$

Dapat disimpulkan bahwa perilaku konsumen adalah sebagai studi tentang proses pengambilan keputusan oleh konsumen dalam memilih, membeli, memakai serta memanfaatkan produk, jasa, gagasan atau pengalaman dalam rangka memuaskan kebutuhan dan hasrat konsumen. Perilaku seorang konsumen dapat dipengaruhi oleh ${ }^{24}$ mindset bahwa konsumen adalah raja serta motivasi dan perilaku konsumen.

Di dalam teori perilaku konsumen disebutkan bahwa permintaan konsumen terhadap barang dan

${ }^{23}$ Freddy Rangkuti, Strategi Promosi yang Kreatif dan Analisis Kasus Integrated Marketing Communication, (Jakarta: PT Gramedia Pustaka Utama, 2009), h. 91.

${ }^{24} \mathrm{Http}$ ://esty.staff.uns.ac.id/definisi-perilaku-konsumen/, diunduh pada 10 September 2013. jasa akan dipengaruhi oleh beberapa faktor, antara lain: pendapatan, selera konsumen dan harga barang, di saat kondisi yang lain tidak berubah (cateris paribus). Seseorang dengan pendapatan yang diperolehnya dapat membeli pelbagai barang dan jasa sehingga tercapai kepuasan tertentu sesuai dengan apa yang diharapkannya. Perilaku konsumtif pada konsumen ini sangat berkaitan erat dengan bidang pemasaran. Menurut American Marketing Association, perilaku konsumen dapat diartikan sebagai interaksi dinamis antara afeksi dan kognisi, perilaku dan lingkungan, yang mana manusia melakukan pertukaran dalam pelbagai aspek dalam kehidupan mereka. Perilaku konsumen sangat bergantung pada pengetahuan pelayanan dan pengaruh pada konsumen. Perilaku konsumen dapat disimpulkan sebagai berikut: ${ }^{25}$ (1) Perilaku konsumen adalah dinamis, karena pemikiran, perasaan dan tindakan dari setiap individu konsumen, kelompok sasaran konsumen dan masyarakat secara keseluruhan adalah selalu berubah. (2) Perilaku konsumen melibatkan interaksi antara pemikiran orang-orang, perasaan, tindakan dan lingkungan. (3) Perilaku konsumen melibatkan pertukaran. Pertukaran ini terjadi pada sesama manusia.

Penggunaan kartu kredit syariah pada bank syariah telah memberikan batasan dari besaran pembelanjaan atas transaksi yang dilakukan oleh pihak pengguna kartu. Ada batasan maksimal yang telah dipatok oleh pihak penerbit kartu bagi nasabah yang akan melakukan transaksi agar nasabah dapat menghindari perilaku konsumtif yang berlebih-lebihan (isrâf) yang berdampak pada ketidakmampuan nasabah membayar tagihan. Berdasarkan hasil penelitian yang dilakukan oleh Handi Irawan $^{26}$, perilaku konsumen Indonesia pada umumnya memiliki 10 (sepuluh) kategori, yaitu: (1) Berpikir jangka pendek (short term perspective), yang terlihat dari cirinya adalah mencari yang serba instant. (2) Tidak terencana (dominated by unplanned behaviour), yang tercermin pada kebiasaan membeli produk yang kelihatannya menarik tanpa perencanaan sebelumnya. (3) Suka berkumpul/sosialisasi sehingga banyak konsumen yang membeli bukan karena kebutuhan tetapi karena faktor pergaulan/sosialita. (4) Berorientasi pada konteks bukan pada esensi barang sehingga menyebabkan konsumen lebih tertarik pada kemasan barang. (5) Gengsi (putting prestige as important motive). (6) Budaya lokal (strong in subculture). (7) Kurang peduli lingkungan sehingga mereka mampu membeli namun penggunaannya

\footnotetext{
${ }^{25}$ J. Paul Peter \& Jerry C. Olson, Consumer Behaviour \& Marketing Strategy, (T.t.: McGraw-Hill/Irwin, 2008), h. 432-400.

${ }_{26} \mathrm{Http}: / /$ forum.kompas.com/, diunduh pada 10 September
} 2013. 
kurang tepat. (8) Faktor iklan yang disampaikan oleh tokoh masyarakat/tokoh agama. (9) Suka buatan luar negeri/barang-barang impor yang kenyataannya saat ini barang-barang tersebut mengalir deras memasuki pasar Indonesia dengan harga yang jauh lebih murah dan kualitas lebih baik. (10) Gagap teknologi sehingga mengakibatkan tidak terlalu memperhatikan elemenelemen dari suatu produk.

Dari beberapa karakter perilaku konsumen Indonesia, pada umumnya tampak bahwa konsumen Indonesia adalah konsumen yang selalu ingin memenuhi kepuasan untuk mendapatkan suatu produk, barang dan jasa secara cepat dan instant serta harga terjangkau, sehingga membuat para produsen atau distributor produk barang dan jasa lebih memikirkan untuk meningkatkan pelayanan dan strategi pasar daripada esensi barang dan jasa yang ditawarkan. Menjamurnya bisnis online dan pembayaran yang dapat dilakukan melalui financial card, baik debit maupun kredit, memberikan kemudahan tersendiri bagi konsumen untuk membelanjakan sejumlah uangnya untuk mendapatkan barang dan jasa yang diinginkan. Akibatnya, sebagaimana yang dilansir oleh Koran Kompas edisi 7 Desember 2012 bahwa konsumen Indonesia saat ini lebih senang menggunakan kartu kredit dibandingkan kartu debit. Hal ini dikarenakan kartu kredit memungkinkan seorang konsumen melakukan pembelian barang lebih dulu dengan pembayaran di kemudian hari. Konsekuensinya adalah pendapatan yang diterima nasabah seringkali lebih banyak digunakan untuk membayar tagihan-tagihan yang diterima.

Persoalan kartu kredit syariah tidak boleh menjadikan pemakaiannya menjadi berlebihan/konsumtif/isrâf, sementara kartu kredit sendiri memiliki kecenderungan menjadikan penggunanya menjadi konsumtif. Pemberlakuan pagu limit berdasarkan jenis kartu pun sebenarnya lebih memudahkan bagi pihak penerbit kartu dalam mengelompokkan nasabah pengguna berdasarkan kemampuan pembayaran tagihan, tetapi tidak mampu menekan keinginan nasabah untuk memenuhi kepuasan materil akan memperoleh barang dan jasa tertentu. Sebab, pada dasarnya kartu kredit tetap dilandasi pada analogi menganjurkan orangorang untuk berutang, padahal di dalam hukum Islam berutang merupakan salah satu hal yang tidak dianjurkan.

Hasil penelitian yang dilansir dari Republika ${ }^{27}$ menyatakan bahwa rasio belanja dibanding pendapatan

\footnotetext{
${ }^{27}$ Www.republika-online.com, diunduh pada 16 Oktober 2013.
}

atau marginal propensity to consume penduduk Indonesia telah melebihi angka satu. Artinya, banyak penduduk Indonesia berbelanja melebihi pendapatan dan sebagian disebabkan karena kartu kredit. Karena itu, pada dasarnya kartu kredit tidak sesuai dengan semangat yang dibangun dan dijalani dalam ekonomi syariah. Akibatnya bisa diperkirakan akan meningkatkan tingkat kredit macet pada kartu kredit.

Dalam ekonomi syariah, ada yang dikenal dengan istilah yudfa' asyadd al-dhdhararayn, yang maksudnya adalah transaksi yang pada awalnya dilarang dapat dibolehkan dengan dasar tidak ada pilihan lain dan untuk mengambil hal yang mudaratnya lebih ringan. Ekonomi Islam atau ekonomi syariah tidak dapat melepaskan diri dari aspek penyediaan jawaban dari sudut pandang agama yang tidak hanya mengandalkan dari sudut pandang materialisme atau aspek market saja. ${ }^{28}$

Globalisasi menuntut suatu level playing fields antar bank. ${ }^{29}$ Oleh karena itu, banyak dijumpai adanya suatu proses penyeragaman atau minimal terjadinya kesebandingan dari pelbagai ketentuan maupun jenis kegiatan usaha bank, sehingga salah satu dampak yang menimpa pada masyarakat Islam sendiri adalah munculnya produk kartu kredit syariah sebagai pembiayaan konsumer.

Semakin terbukanya international financial access, mendorong perusahaan-perusahaan, termasuk bank, untuk mencari dana yang lebih murah. Akibatnya, banyak bank, termasuk bank syariah, yang akan kehilangan bisnis corporate banking-nya dengan beralih pada target market yang masih mau mengambil dan menggunakan kredit yang bersifat konsumtif. Atau dengan kata lain, beberapa bank syariah mulai menggarap bisnis consumer banking ketimbang corporate banking. Yang terjadi kemudian adalah banyak calon nasabah yang diiming-iming dengan pelbagai program hadiah yang akan mendorong umat untuk bersikap semakin konsumtif.

Pada masa sekarang dimana teknologi telah berkembang pesat, maka bentuk perilaku dalam memperoleh kemewahan telah lahir dalam bentuk lain, salah satunya adalah penggunaan kartu kredit syariah/ kartu syariah, sebagai salah satu bentuk pembiayaan konsumer. Sebab, jika diperhatikan bagaimana semangat umum syariah, sistem nilai dan pendistribusian kekayaan dalam masyarakat menurut syariah, maka

\footnotetext{
${ }^{28}$ Abdul Aziz dan Mariyah Ulfah, Kapita Selekta Ekonomi Islam Kontemporer, h. 255-256.

29 Zainul Arifin, Memahami Bank Syariah, Lingkup, Peluang, Tantangan dan Prospek, h. 70.
} 
konsep tanâum/pemborosan dapat didefinisikan sesuai dengan perkembangan dari waktu ke waktu.

Perilaku atau paradigma yang diterapkan dalam kehidupan sehari-hari bagi masyarakat Islam harus ada skala prioritas. Oleh karena itu, penggunaan kartu kredit syariah dan sejenisnya bukanlah pada tingkatan martabat dharûriyyât (primer) karena selama masih ada jenis pembiayaan lain yang lebih mudah diterima maka kartu kredit ini tidak diperlukan. Jadi, kartu kredit sebenarnya merupakan kategori martabat hâjjiyyât (sekunder) atau bahkan martabat tabsîniyyât/kamâliyyât (pelengkap) apabila masih dapat digunakan jenis pembiayaan lain, misalnya kartu debit. Oleh karena itu, kartu kredit dibolehkan apabila memang fasilitas kartu debit atau pembayaran tunai tidak ada dan bukan menjadi suatu kebutuhan pokok. ${ }^{30}$

\section{Penutup}

Berdasarkan dari apa yang telah diuraikan di atas, maka keberadaan dan penggunaan kartu kredit syariah sebagai salah satu produk jasa bank syariah yang diperuntukan dalam kegiatan pembiayaan konsumer, memberikan pengaruh yang sangat besar dalam peningkatan kegiatan transaksi konsumsi masyarakat, khususnya masyarakat Muslim. Dikarenakan dalam kartu kredit syariah tidak ada sistem kontrol untuk memastikan apakah pemegang kartu menggunakan kartunya untuk membelanjakan barang-barang yang halal dan pagu batas penggunaan kartu tidak dapat menjadikan pemegangnya untuk tidak menjadi konsumtif. Padahal ini jelas-jelas bertentangan dengan prinsip syariah, sebab sifat konsumtiflebih menekankan pada kepuasan diri dalam memenuhi bidang materiil yang bersifat sesaat (Q.s. al-Jâtsiyah [45]: 18).

Disamping itu, penggunaan kartu kredit syariah yang dapat meningkatkan rasio belanja masyarakat, akan mempengaruhi naiknya tingkat kredit macet dari sektor pembiayaan konsumer, sehingga akan membawa pengaruh pada keadaan perekonomian dan keuangan negara.

Semangat ekonomi syariah yang dibangun atas dasar kebersamaan dari pelbagai pihak yang harus dilaksanakan dengan cara antara lain: (1) Kebebasan dalam berekonomi. (2) Keseimbangan hak individu dan hak kolektif. (3) Berorientasi pada kemaslahatan dan manfaat. (4) Etika bisnis dan ekonomi yang mendasarkan pada kejujuran, prinsip otonomi dan keadilan.

${ }^{30}$ Abdul Aziz dan Mariyah Ulfah, Kapita Selekta Ekonomi Islam Kontemporer, h. 257-258.
Jika ditinjau dari sisi kemaslahatan dan manfaat, mengingat pola perilaku konsumen masyarakat Indonesia yang masih sangat mengikuti trend bukan pada kebutuhan, lebih melihat kemasan yang menarik, lebih karena dorongan kelompok sosial dan merupakan konsumen instant, maka keberadaan kartu kredit menjadi pemicu meningkatnya perilaku konsumtif masyarakat Muslim di Indonesia. Efek-efek negatif ini hanyalah merupakan akibat dari peniruan gaya hidup dan pola pikir yang tidak berdasarkan nilai-nilai ekonomi syariah.

Upaya yang dapat dilakukan oleh bank syariah dalam melakukan pengembangan tidak hanya yang bersifat jangka pendek, tetapi juga harus merupakan pengembangan jangka panjang, seperti restrukturisasi dan reengineering, agar kondisi bank selalu sehat dengan ditunjang seperangkat peraturan hukum dalam bidang perbankan syariah. []

\section{Pustaka Acuan}

\section{Buku:}

Ahmad, Syaykh Mahmûd, Economics of Islam, Lahore: Ashraf Publications, 1968.

Arifin, Zainul, Memahami Bank Syariah, Lingkup, Peluang, Tantangan dan Prospek, Jakarta: Alvabet, 1999.

Aziz, Abdul dan Mariyah Ulfah, Kapita Selekta Ekonomi Islam Kontemporer, Bandung: Penerbit Alfabeta, 2010.

Dewi, Gemala, dkk., Hukum Perikatan Islam di Indonesia, Jakarta: Kencana, 2006, Edisi 1, Cet. 2.

Khan, Muhammad Akram, Ajaran Nabi Muhammad Saw. tentang Ekonomi (Kumpulan Hadits-Hadits Pilihan tentang Ekonomi), Jakarta: Bank Muamalat Indonesia, 1997.

Mannan, Islamic Economics, Lahore: Ashraf Publications, 1970.

Mo'tamar al-Alam al-Islami, Quelques Aspects Economiques de l' Islam, Karachi: Mo'tamar al-Alam al-Islami, 1964.

Mushlih, Abdullah dan Shalah Shawi, Fiqih Ekonomi Keuangan Islam, Jakarta: Darul Haq, 2004.

Nawawi, Ismail, Ekonomi Kelembagaan Syariah dalam Pusaran Perekonomian Global; Sebuah Tuntutan dan Realitas, Surabaya: Putra Media Nusantara, 2009.

Peter, J. Paul \& Jerry C. Olson, Consumer Behaviour \& Marketing Strategy, T.t.: McGraw-Hill/Irwin, 2008.

Rahman, Afzalur, Doktrin Ekonomi Islam, Jakarta: Penerbit Dana Bhakti Wakaf, 1995.

Rangkuti, Freddy, Strategi Promosi yang Kreatif dan Analisis Kasus Integrated Marketing Communication, 
Jakarta: PT Gramedia Pustaka Utama, 2009.

Sulaiman, Abdul Wahab Ibrahim Abu, Banking Cards Syariah Kartu Kredit dan Debit dalam Perspektif Fiqih, Jakarta: Raja Grafindo Persada, 2006.

Weber, Max, The Protestant Ethic and The Spirit of Capitalism, New York: Charles Scribners Sons, 1958.

\section{Website:}

Http://esty.staff.uns.ac.id/definisi-perilakukonsumen/, diunduh pada 10 September 2013.

Http://forum.kompas.com/, diunduh pada 10
September 2013.

Http://safruddin.wordpress.com/, diunduh pada 25 Juli 2013.

Ridawati, Mujiatun, "Konsep Kartu Kredit (Bithâqah I'timân) sebagai Alat Pembayaran dalam Hukum Islam, dalam www.wordpress.com, diunduh pada tanggal 19 Juli 2013.

Www.infobanknews.com, diunduh pada 10 September 2013.

Www.republika-online.com, diunduh pada 16 Oktober 2013. 